\title{
THE EFFECTS OF SEEDING TIME AND COMPANION CROP ON YIELD OF ALFALFA (Medicago sativa L.) AND WEED GROWTH
}

\author{
Irfan CORUH $H^{*}$, Mustafa TAN ${ }^{2}$ \\ ${ }^{1}$ Ataturk University, Faculty of Agriculture, Department of Plant Protection, Erzurum, TURKEY \\ ${ }^{2}$ Ataturk University, Faculty of Agriculture, Department of Field Crops, Erzurum, TURKEY \\ ${ }^{*}$ Corresponding author: icoruh@atauni.edu.tr
}

Received: 13.05.2016

\begin{abstract}
Weed control with cultural methods is of great importance for perennial forages. This study was planned in order to determine the effects of seeding time and mixed seeding of alfalfa with wheat on hay yield and weed growth. The study was carried out in the irrigated area of Atatürk University, Faculty of Agriculture in 2014 and 2015. Alfalfa was seeded in two different seasons (spring and summer) as a sole crop and as a mixture with wheat. The research was established in a randomized complete blocks design with four replications. Dry matter yield, alfalfa plant height, weed rate, weed biomass production, weed frequency and density were examined in the study. Research results revealed that mixed seeding of alfalfa with wheat under the irrigated conditions of Erzurum Region increased the dry matter yield both in the first and the following year. This application also reduced the biomass production of weed and the weed rate of hay. Seeding in summer months instead of spring reduced the dry matter yield in the first year, but it was found more effective in terms of weed control.
\end{abstract}

Keywords: Alfalfa, seeding time, mixture crop, weeds

\section{INTRODUCTION}

One of the most important problems of alfalfa cultivation is weed infestation. If the necessary measures are not taken in the first year, the weed infestation is observed on poor growing alfalfa fields. Weed competition in new alfalfa plantings can cause permanent damage to the productivity of the stand. Competitive effects of weeds during early growth can extend well into the first year, the second year, and often throughout the life of the stand (Canevari et al. 2007). Therefore, certain measures must be taken during seeding for weed control. Weed control during alfalfa stand establishment involves integrating many cultural practices like mixed cropping and adjusting sowing time. One of the most important cultural practices for controlling weeds is to plant at an optimum time for the alfalfa seedling growth, and when weed populations and growing conditions do not favor the weeds (Canevari et al 2007). Each seeding time has some advantages and disadvantages, and they vary depending on the ecological conditions of the region. Alfalfa seeded the traditional planting time in spring when sown, summer annual weeds and grasses germinate, grow more rapidly and compete vigorously with the alfalfa. On the other hand, it is suggested that winter alfalfa seeding in the autumn has some advantages such as less root rot, less seedling diseases and less weed density (Rankin 2001; McAlavy 2002). Alfalfa is seeded in spring as a summer plant in the Eastern Anatolia Region, for it is damaged by the cold during the seedling period. However, Tan et al. (2009) stated that the late summer seeding to be held in August on irrigation fields would give plants the opportunity to grow and root before killing colds, and the plants seeded in this period passed the winter period without any problem. Late summer seeding is an excellent way to establish stands and is actually the preferred time of year to seed in many regions. Allows seeding of alfalfa following the summer harvest of small grains. Weeds are primarily controlled by pre-plant cultivation or burn down, reducing the need for herbicides. Therefore, seeding in summer season may be an effective method of weed control without using chemicals. There is a need for the studies in which the yield of alfalfa seeding in the summer season, as well as the weed development in our region, are investigated.

The first year is the establishment period for perennial forages like alfalfa and the plants show a weak growth. This situation leads to a low yield from the field as well as weed infestation. The weed rate on alfalfa fields is increasing each passing year depending on the aging stands (Coruh and Tan, 2008). Mixed seeding with an annual plant species such as wheat showing rapid development is applied in order to eliminate these disadvantages. A form of mixed planting with companion crops (e.g., wheat, barley and oat) prevent suppress weeds while the alfalfa is becoming establishment (Tan and Serin, 1998; Tan and Serin, 2004; Lanini et al. 1991). Because a vigorous stand reduces the amount of sun light reaching the soil surface, inhibiting 
weeds from germinating and becoming established. However, companion crops can reduce subsequent alfalfa yields and alfalfa stand densities (Lanini et al. 1991). Moreover, there are not enough studies conducted on which weed the mixed seeding on alfalfa fields is effective and the weed density and frequency. Acar et al. (2010; 2011) reported that the suppressed weed species varied depending on the companion crop species used. Studies show that using some cultural practices that support longer alfalfa stand life and higher yields generally provides weed-free fields. Therefore, this study was performed in order to determine the effects of seeding the sole crop or mixed crop with wheat in the spring and summer periods on the alfalfa yield and the weed growth on the fields.

\section{MATERIALS AND METHODS}

The study was performed in irrigated area of Atatürk University, Faculty of Agriculture in 2014 and 2015 based on the randomized complete block design as four replications. In this study, alfalfa (Medicago sativa $\mathrm{L}$. var. Bilensoy) was seeded in two different periods, which were spring (May) and summer (August). Seeding was performed both as a sole crop and mixed with wheat. Alfalfa was sown at $20 \mathrm{~kg} \mathrm{ha}^{-1}$ in $30 \mathrm{~cm}$ row spacing. Plots size were $3.0 \mathrm{~m}$ long by $1.5 \mathrm{~m}$ wide ( 5 rows). Fertilizer was applied during seeding at the rate of $50 \mathrm{~kg} \mathrm{~N} \mathrm{ha}^{-1}$ and 100 $\mathrm{kg} \mathrm{P}_{2} \mathrm{O}_{5} \mathrm{ha}^{-1}$. Only $150 \mathrm{~kg} \mathrm{P}_{2} \mathrm{O}_{5} \mathrm{ha}^{-1}$ was applied in the second year (Tan and Serin, 2013). Alternative Kırik wheat species (Triticum aestivum L.) was used as a companion crop. Wheat was seeded by broadcasting into parcels at the rate of $100 \mathrm{~kg} \mathrm{ha}^{-1}$ before seeding alfalfa (Tan and Serin, 2004).

Irrigation was performed once every 8-10 days starting from June for spring seeding and from the date of seeding for summer seeding. The parcels which had been mixedseeded during spring seeding were harvested in the period of milk in wheat in the first year, and the parcels which had been seeded as a sole crop were harvested 15 days before the killing cold (the first week of October). All parcels which had been seeded in the summer were harvested in the first week of October. In the second year, harvest was made at the beginning of the flowering of alfalfa (Tan and Serin, 2013). Dry matter yield was determined by harvesting $2 \mathrm{~m}$ x $0.9 \mathrm{~m}$ strip from the middle of the plots. Fresh plants were weighed and dried by being left in the open air first and then in the drying oven at $65^{\circ} \mathrm{C}$ for 48 hours, and then their dry matter yield was determined. During the harvest, measurements were performed in terms of plant height and weed rate of hay. Two harvests were made in the second year, and the dry matter yield was determined as the total amount obtained in two harvests, and plant height was determined as the average of the values obtained in two harvests.

The weed rate $(\%)$, biomass production $\left(\mathrm{g} \mathrm{m}^{-2}\right)$, density (unit $\mathrm{m}^{-2}$ ) and frequency (\%) were determined by frames of $1 \mathrm{~m}^{2}$ which were randomly thrown in the parcels. Weed ratio of hay (\%) was determined on a dry weight basis by separately weighing alfalfa and weed in the area of $1 \mathrm{~m}^{2}$ randomly chosen from each parcel. The density of weed

was determined by separately counting the weed species in the frame. The frequency of occurrence was determined using the following formula: The number of frames in which this species was found / Total number of frames $x$ 100 (Uygur, 1985).

The average annual temperature in Erzurum province where this study was performed in 2014 and 2015 was 6.7 ${ }^{\circ} \mathrm{C}$ and $7.4{ }^{\circ} \mathrm{C}$, respectively. The total annual rainfall was recorded as $342.8 \mathrm{~mm}$ and $433.5 \mathrm{~mm}$. The average temperature of the years when the experiment was occurred was higher than the average long-term temperature (19502013); the total rainfall in 2014 was less than the average long-term rainfall while it was higher in 2015 than the average long-term rainfall.

The texture of the experiment soil is clay loam, and total salt was $0.05 \%, \mathrm{pH}$ was 7.41 , lime was $1.5 \%$, plantavailable $\mathrm{P}_{2} \mathrm{O}_{5}$ was $62 \mathrm{~kg} \mathrm{ha}^{-1}, \mathrm{~K}_{2} \mathrm{O}$ was $1180 \mathrm{~kg} \mathrm{ha}^{-1}$, and organic matter was $0.85 \%$. According to these values, the experiment soil is salt-free, slightly alkaline, light calcareous, poor in plant-available phosphorus, rich in potassium and very poor in organic matter (Anonymous 1991).

The data obtained from this study were subjected to the variance analysis according to the split-plot test design; years were located in the main parcels, and seeding times and companion crop applications were located in the subparcels. The differences between the averages which were found significant were identified with the LSD test (Y1ldiz and Bircan, 2003).

\section{RESULTS AND DISCUSSION}

\section{Dry Matter Yield}

In this study, $4080 \mathrm{~kg} \mathrm{ha}^{-1}$ dry matter yield was obtained in the first year, and this yield reached $8734 \mathrm{~kg} \mathrm{ha}^{-1}$ in the second year with a significant increase (Table 1). The yield was low in the first year for it was the seeding year. Since plants make their real production in the second year, dry matter yield was higher in the second year. Seeding alfalfa as the sole crop or with a companion crop in different periods significantly affected dry matter yields. The yield obtained from spring seeding (7385 kg ha-1) was higher than that obtained from summer seeding $\left(5433 \mathrm{~kg} \mathrm{ha}^{-1}\right)$. The impact of the first year yield on these results was great. The yield obtained from spring seeding was higher since early seeding provided a longer growth period (Tan et al. 2009). Similarly, seeding with wheat as a companion crop significantly increased the first year yield since perennials are unable to show adequate development in the first year. Therefore, the field surface remains nearly empty. However, if seeding is performed with wheat as a companion plant, which is a fast-growing annual plant, then, a high yield can be obtained from the field in the first year. This has been revealed in many studies on companion crops (Lanini et al. 1991; Tan and Serin 2004; Acar et al. 2011). 
Table 1. Effects of seeding time and companion crop on dry matter yield and plant height of alfalfa in the establishment and subsequent year

\begin{tabular}{|c|c|c|c|c|c|c|c|}
\hline \multirow{2}{*}{ Seeding Time } & \multirow{2}{*}{ Mixture } & \multicolumn{3}{|c|}{ Dry Matter Yield (kg ha $\left.{ }^{-1}\right)$} & \multicolumn{3}{|c|}{ Plant Height (cm) } \\
\hline & & 2014 & 2015 & Mean & 2015 & 2014 & Mean \\
\hline \multirow{2}{*}{ Spring } & Solo-seeding & 3420 & 9397 & 6408 & 47.0 & 58.0 & 52.7 \\
\hline & Mixed-seeding & 7200 & 9523 & 8362 & 30.0 & 56.3 & 43.2 \\
\hline Mean & & 5310 & 9460 & $7385 \mathrm{a}$ & 38.7 & 57.2 & $47.9 \mathrm{a}$ \\
\hline \multirow{2}{*}{ Summer } & Solo-seeding & 1757 & 7760 & 4758 & 24.0 & 64.7 & 44.3 \\
\hline & Mixed-seeding & 3943 & 8270 & 6107 & 18.3 & 64.3 & 41.3 \\
\hline \multirow[t]{3}{*}{ Mean } & & 2850 & 8015 & $5433 \mathrm{~b}$ & 21.2 & 64.5 & $42.8 \mathrm{~b}$ \\
\hline & Solo-seeding & 2588 & 8578 & $5583 \mathrm{~b}$ & 35.7 & 61.3 & $48.5 \mathrm{a}$ \\
\hline & Mixed-seeding & 5572 & 8897 & $7234 \mathrm{a}$ & 24.2 & 60.3 & $42.3 \mathrm{~b}$ \\
\hline Mean & & $4080 \mathrm{~b}$ & $8734 \mathrm{a}$ & 6407 & $29.9 \mathrm{~b}$ & $60.8 \mathrm{a}$ & 45.4 \\
\hline \multicolumn{8}{|l|}{$F$ test $(L S D)$} \\
\hline \multicolumn{2}{|l|}{ Year } & \multicolumn{3}{|c|}{$* *(541)$} & \multicolumn{3}{|c|}{$* *(7.1)$} \\
\hline \multicolumn{2}{|l|}{ Seeding Time } & \multicolumn{3}{|c|}{$* *(541)$} & \multicolumn{3}{|c|}{$*(5.1)$} \\
\hline \multicolumn{2}{|l|}{ Mixture } & \multicolumn{3}{|c|}{$* *(541)$} & \multicolumn{3}{|c|}{$*(5.1)$} \\
\hline \multicolumn{2}{|c|}{ Year x Seeding Time } & \multicolumn{3}{|c|}{$*(552)$} & \multicolumn{3}{|c|}{$* *(10.0)$} \\
\hline \multicolumn{2}{|c|}{ Year x Mixture } & \multicolumn{3}{|c|}{$* *(765)$} & \multicolumn{3}{|c|}{$* *(7.2)$} \\
\hline \multicolumn{2}{|c|}{ Seeding Time x Mixture } & \multicolumn{3}{|c|}{ ns } & \multicolumn{3}{|c|}{ ns } \\
\hline \multicolumn{2}{|c|}{ Year x S. Time x Mixture } & \multicolumn{3}{|c|}{ * (780) } & \multicolumn{3}{|c|}{ ns } \\
\hline
\end{tabular}

Means in the same columns and lines followed by the same letters are not significantly different

$*$ : $\mathrm{P}<0.05, * *: \mathrm{P}<0.01, \mathrm{~ns}$ : nonsignificant

\section{Plant Height of Alfalfa}

As expected, the plant height of alfalfa in the seeding year was shorter compared to the second year (Table 1). Alfalfa seeded in the spring in the first year was taller than those seeded in the summer season since they had a longer growth period. However, alfalfa seeded in the summer season in the second year was taller. The plant height of alfalfa seeded as the sole crop in the first year was found taller. This situation was more apparent in 2014 when seeding was performed, for mixed seeding with a companion crop which grows fast created pressure on the growth of alfalfa in the first year. Low light intensity caused a weaker development of alfalfa seedlings (Haskins and Gorz, 1975; Simmons et al. 1995).

\section{Weed Rate}

Weed rate which had been $44.6 \%$ in the parcels in the seeding year decreased to $12.9 \%$ in the following year as alfalfa covered the field surface (Table 2). Weed rate did not show a significant difference according to the seeding time. However, the weed rate in sole crop seeding was much higher than that in mixed seeding with a companion crop $(49.5 \%$ and $8.0 \%$, respectively). Mixed seeding with a companion crop significantly reduced the weed growth on alfalfa fields. While the weed rate in the parcels seeded as the sole crop in the first year was $82.5 \%$, it decreased to $16.5 \%$ in mixed seeding with a huge decrease since in mixed applications, the companion crop formed the most important part of the harvest $(65-82 \%)$ in the first year (Figure 1). The highest companion crop rate was observed in summer seeding in 2014 , and the least weed rate was determined in the same application in 2015 (Figure 1). The effects of the applications made in the first year on weed rate continued in the second year. In the second year, the least weed rate $(8 \%)$ was observed in the mixed-seeded parcels in the summer season, and the highest weed rate (18.3\%) was observed in the sole-crop parcels seeded in the spring (Table 2 and Figure 1). For perennial plants, higher weed infestation is observed in the first year, for there is not a strong plant cover on the field. Therefore, weeds are observed more frequently in alfalfa fields in the first year (Moyer 1985). Mixed seeding with a companion crop like wheat significantly reduces the growth of weed. Lanini et al. (1991) found out that a proper companion crop application in alfalfa farming reduced the weed growth both in the seeding year and the following year. 
Table 2. Effects of seeding time and companion crop on weed rate of hay and weed biomass production in the alfalfa establishment and subsequent year

\begin{tabular}{|c|c|c|c|c|c|c|c|}
\hline \multirow{2}{*}{$\begin{array}{l}\text { Seeding } \\
\text { Time }\end{array}$} & \multirow{2}{*}{ Mixture } & \multicolumn{3}{|c|}{ Weed Rate (\%) } & \multicolumn{3}{|c|}{ Weed Biomass $\left(\mathrm{g} \mathrm{m}^{-2}\right)$} \\
\hline & & 2014 & 2015 & Mean & 2014 & 2015 & Mean \\
\hline & Solo-seeding & 80.0 & 18.3 & 49.2 & 273.7 & 172.1 & 223.0 \\
\hline Spring & Mixed-seeding & 8.3 & 10.7 & 9.5 & 59.9 & 101.7 & 80.8 \\
\hline Mean & & 44.2 & 14.5 & 29.3 & 166.8 & 136.9 & $151.9 \mathrm{a}$ \\
\hline \multirow{2}{*}{ Summer } & Solo-seeding & 85.0 & 14.7 & 49.8 & 147.7 & 113.8 & 130.8 \\
\hline & Mixed-seeding & 5.0 & 8.0 & 6.5 & 19.7 & 67.0 & 43.4 \\
\hline \multirow[t]{3}{*}{ Mean } & & 45.0 & 11.3 & 28.2 & 83.7 & 90.4 & $87.1 \mathrm{~b}$ \\
\hline & Solo-seeding & 82.5 & 16.5 & $49.5 \mathrm{a}$ & 210.7 & 142.9 & $176.9 \mathrm{a}$ \\
\hline & Mixed-seeding & 6.7 & 9.3 & $8.0 \mathrm{~b}$ & 39.8 & 84.3 & $62.0 \mathrm{~b}$ \\
\hline Mean & & $44.6 \mathrm{a}$ & $12.9 \mathrm{~b}$ & 28.8 & $125.3 \mathrm{a}$ & $113.6 \mathrm{~b}$ & 119.5 \\
\hline \multicolumn{8}{|c|}{$F$ test $(L S D)$} \\
\hline \multicolumn{2}{|l|}{ Year } & \multicolumn{3}{|c|}{$* *(3.3)$} & \multicolumn{3}{|c|}{$* *(9.1)$} \\
\hline \multicolumn{2}{|c|}{ Seeding Time } & \multicolumn{3}{|c|}{ ns } & \multicolumn{3}{|c|}{$* *(34.9)$} \\
\hline \multicolumn{2}{|l|}{ Mixture } & \multicolumn{3}{|c|}{$* *(3.3)$} & \multicolumn{3}{|c|}{ ns } \\
\hline \multicolumn{2}{|c|}{ Year x Seeding Time } & \multicolumn{3}{|c|}{ ns } & \multicolumn{3}{|c|}{$* *(49.4)$} \\
\hline \multicolumn{2}{|c|}{ Year x Mixture } & \multicolumn{3}{|c|}{$* *(4.7)$} & \multicolumn{3}{|c|}{$*(35.2$} \\
\hline \multicolumn{2}{|c|}{ Seeding Time x Mixture } & \multicolumn{3}{|c|}{ ns } & \multicolumn{3}{|c|}{ ns } \\
\hline \multicolumn{2}{|c|}{ Year x S. Time x Mixture } & \multicolumn{3}{|c|}{ ns } & \multicolumn{3}{|c|}{ ns } \\
\hline
\end{tabular}

Means in the same columns and lines followed by the same letters are not significantly different

$*: \mathrm{P}<0.05, * *: \mathrm{P}<0.01, \mathrm{~ns}$ : nonsignificant

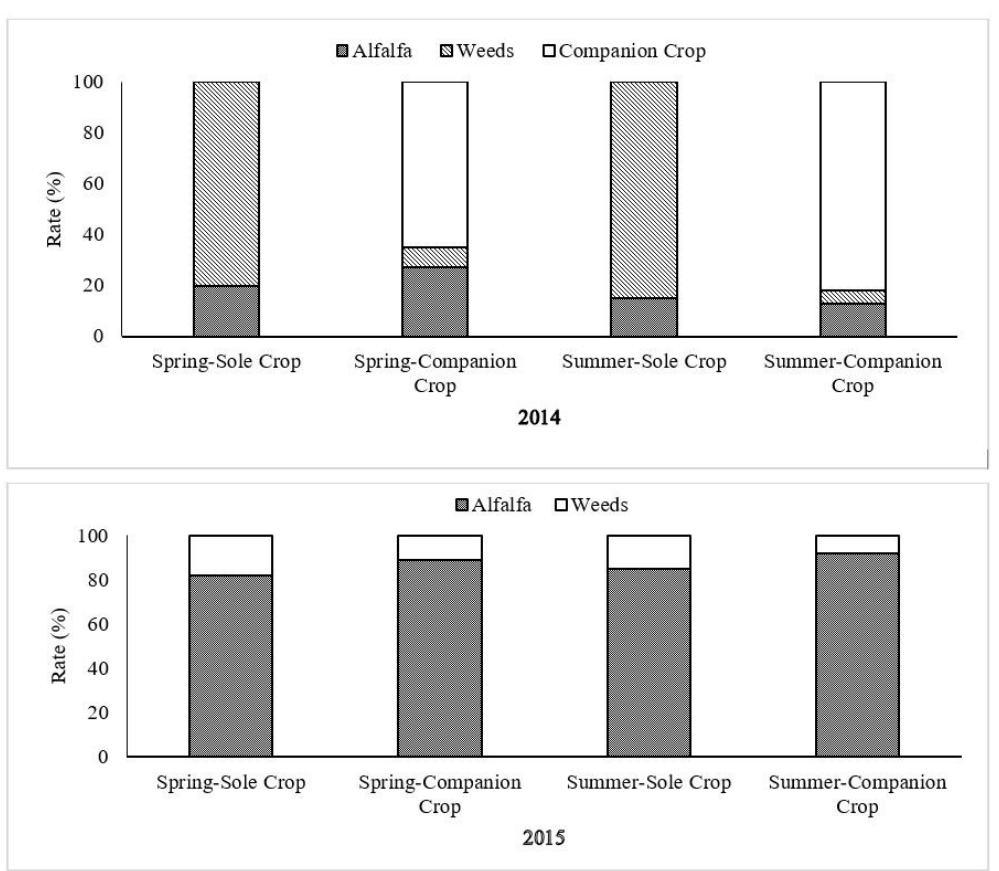

Figure 1. Effects of different treatments on alfalfa, companion crop and weed rates of hay in establishment and subsequent year

\section{Weed Biomass Production}

Weed biomass production per square meter in the first year of the research was higher compared to the second year (Table 2). That alfalfa plants remained as seedlings provided weed with the opportunity to grow and led to this result. Weed biomass production of the seeding performed in the spring season was higher than that of the seeding made in the summer season, for spring seeding provided a longer growth period for the plants (151.9 and $\left.87.1 \mathrm{~g} \mathrm{~m}^{-2}\right)$. Similarly, Çoruh and Bulut (2008) found out that seeding wheat in the spring allowed for a more weed biomass production than seeding in the autumn season. This situation is especially apparent in the first year (166.8 and $83.7 \mathrm{~g} \mathrm{~m}^{-2}$ ). Since weeds had the opportunity to settle in the environment in the seeding year, they continued their 
production in the following year although it reduced slightly (136.9 and $90.4 \mathrm{~g} \mathrm{~m}^{-2}$ ). The impact of mixed seeding with companion crops on weed biomass production was great. While weed biomass production was $176.9 \mathrm{~g} \mathrm{~m}^{-}$ 2 in sole crop seeding, it decreased to $62.0 \mathrm{~g} \mathrm{~m}^{-2}$ in mixedseeding with wheat. This impact which was more apparent in the first year continued in the second year as well. Lanini et al. (1991) found out that companion crop reduced the weed biomass production in alfalfa by $75 \%$.

\section{Weed Density and Frequency}

In the first year of the research, the species observed in the study area were redroot pigweed (Amaranthus retroflexus L.), field bindweed (Convolvulus arvensis L.), common lambsquarters (Chenopodium album L.), Canada thistle (Cirsium arvense (L.) Scop. ), dwarf mallow (Malva neglecta Wallr.) and green foxtail (Setaria viridis (L.) P. Beauv.) (Figure 2). These species, except Cirsium arvense, are annual species and frequently seen in agricultural fields in the region. The density of these species in the seeding year was found to be within $0.08-17.33$ unit $\mathrm{m}^{-2}$ range. The most intense species were A. retroflexus L. (17.33 unit m $\left.{ }^{2}\right)$, C. arvensis L. (8.50 unit $\mathrm{m}^{-2}$ ) and C. album L. (4.33 unit $\mathrm{m}^{-2}$ ). The frequency of occurrence of these species was $100.0 \%, 83.3 \%$ and $75.0 \%$, respectively (Figure 2). These results revealed that $A$. retroflexus $\mathrm{L}$. was observed in all parcels in the seeding year. This situation is in relation to seed stock, competitiveness and spreading properties of the species. In a study carried out in wheat fields in our region, C. arvense (L.) Scop. and C. arvensis L. were found to be the weeds with the highest density (Çoruh and Bulut, 2008).

In the second year of the research, $A$. retroflexus L., $C$. album L., M. neglecta Wallr. and S. viridis (L.) P. Beauv. disappeared in the research area (Figure 2). Locket larkspur (Consolida orientalis (Gay) Schröd.), prickly lettuce (Lactuca serriola L.), flixweed (Descurainia sophia (L.) Webb ex Prantl), tall tumble mustard (Sisymbrium altissimum L.), black bindweed (Vaccaria hispanica (Mill.) Rauschert), yellow star-thistle (Centaurea solstitialis L.), yellow sweet clover (Melilotus officinalis (L.) Desr.), eastern groundsel (Senecio vernalis Waldst. \& Kit.), yellow salsify (Tragopogon dubius Scop.) and broadleaf false carrot (Turgenia latifolia (L.) Hoffm.) were started to be observed instead of them. The most intense species were $C$. arvensis L. (7.40 unit $\left.\mathrm{m}^{-2}\right), C$. orientalis (Gay) Schröd. (2.30 unit $\left.\mathrm{m}^{-2}\right)$, L. serriola $\mathrm{L}$. (1.70 unit $\mathrm{m}^{-2}$ ) and D. sophia (L.) Webb ex Prantl. (0.90 unit $\left.\mathrm{m}^{-2}\right)$, respectively. $C$. arvensis L. was observed in all parcels (100\%), and it was followed by $C$. orientalis (Gay) Schröd (90\%). The least observed species with $10 \%$ frequency rate were $C$. solstitialis (Gay) Schröd., M. officinalis (L.) Desr., S. vernalis Waldst. \& Kit., T. dubius Scop., T. latifolia (L.) Hoffm. and $V$. hispanica (Mill.) Rauschert (Figure 2). In the second year, important species such as A. retroflexus L., C. album L. disappeared but the number of the species in the experiment field increased. However, the frequency and density rates of the new species in the environment were low. In the second year, as alfalfa settled in the field, weed seeds had no opportunity to grow although they germinated.

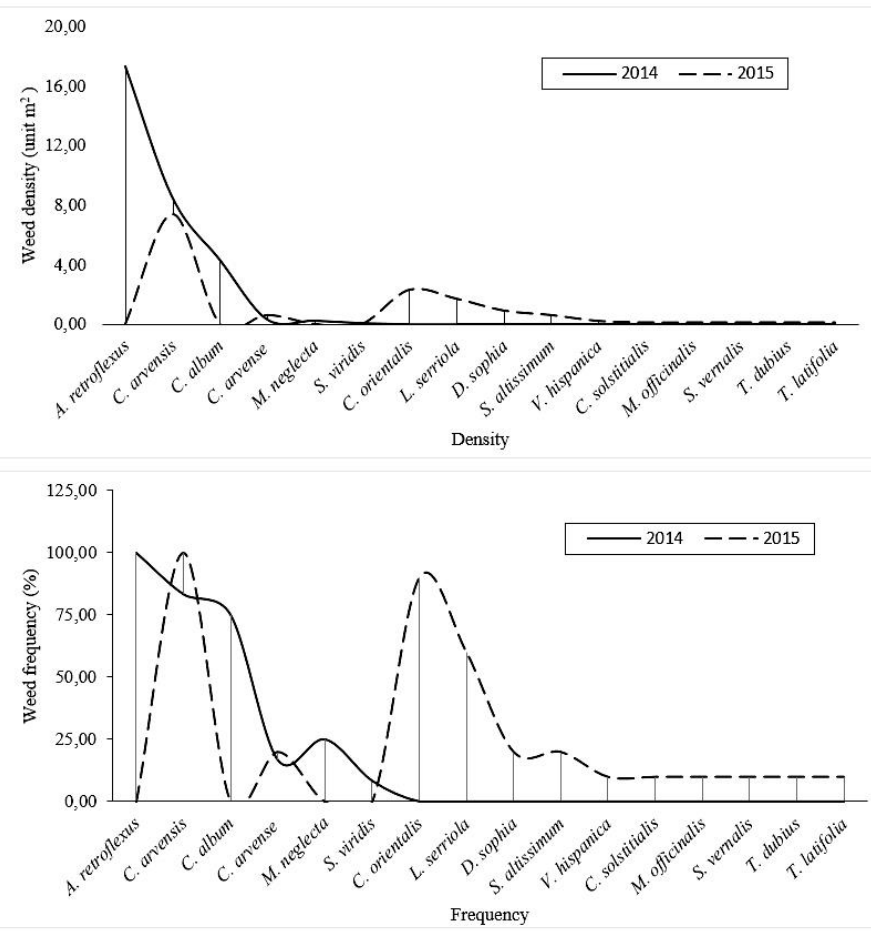

Figure 2. Weed density and frequency in the establishment and subsequent year 


\section{CONCLUSIONS}

The key to the long-lasting and productive alfalfa plant is to prevent weed infestation in the first year. That forage crops cannot show enough growth in the seeding year in the areas with high altitudes makes the weed infestation easier. Therefore, taking some cultural measures for weed control in the seeding year is of great importance. This study revealed that effective weed control could be carried out through some cultural methods without using chemical methods on alfalfa fields in the Eastern Anatolia Region. Since alfalfa farming does not give a lot of products in the first year in our region, the first year is generally considered as a lost year. However, if a companion crop such as wheat is used in seeding, the yield obtained from the field in the first year increases, and no significant problem in the yield is experienced in the following year. This application is also quite effective in terms of weed control. Seeding in the spring increases the yield obtained in the first year, for it provides a longer growth period for plants. However, in the spring seeding, summer weeds have an opportunity to grow as well. Alfalfa can be seeded in the summer after cereals have been removed from the fields in Erzurum conditions. This provides slightly less yield compared to seeding at the beginning of spring. However, it is a more effective application for weed control, for it gives less opportunity for weeds to grow. Therefore, taking the results of this study into consideration, it can be recommended that alfalfa should be seeded in the summer period by mixing with wheat under the conditions of Erzurum.

\section{ACKNOWLEDGEMENTS}

This study was supported by the Research Foundation of Atatürk University (BAP-2013/382).

\section{LITERATURE CITED}

Acar, Z, O.O. Asci, U. Basaran, I. Ayan and H. Mut. 2010. Pea companion crop for red clover establishment. Turkish Journal of Field Crops 15(2): 114-122.

Acar, Z, O.O. Asci, U. Basaran, I. Ayan and H. Mut. 2011. Can triticale be used as a companion crop with red clover? Turkish Journal of Agriculture and Forestry 35: 235-245.

Anonymous, 1991. Turkey Inventory of Soil Productivity. T.C. Ministry of Agriculture, Forestry and Rural Affairs. General Directorate of Rural Services, Ankara.
Canevari, M., R.N. Vargas and S. B. Orloff. 2007. Weed management in alfalfa. University of California Division of Agriculture and Natural Resources, Pub. No: 8294, 12/2007.

Coruh, I. and M. Tan. 2008. Lucerne persistence, yield and quality as influenced by stand aging. New Zealand Journal of Agricultural Research 51: 39-43.

Çoruh, I. and S. Bulut. 2008. Dry weight, density and frequency of weeds in wheat varieties sowing in different time. Journal of Agricultural Sciences 14(3): 276-283.

Haskins, F.A. and H.I. Gorz. 1975. Influence of seed size, planting depth, and companion crop on emergence and vigor of seedlings in sweetclover. Agronomy Journal 67(5): 652-654.

Lanini, W.T., S.B. Orlof, R.N. Vargas, J.P. Orr, V.L. Marble and S.R. Grattan. 1991. Oat companion crop seeding rate effect on alfalfa establishment, yield and weed control. Agronomy Journal 83: 330-333.

McAlavy, T.M. 2002. Spring seeding alfalfa is risky business on the High Plains. Agricultural News and Public Affairs. Texas Univ. Agriculture Program, Feb. 27.

Moyer, J.R. 1985. Effect of weed control and a companion crop on alfalfa and sainfoin establishment, yields and nutrient composition. Canadian Journal of Plant Science 65: 107-116.

Rankin, M. 2001. Establishing alfalfa during late summer. Focus on Forage, Vol: 3, No: 5. Univ. Wisconsin Extension Service. USA.

Simmons, S.R., C.C. Sheaffer, D.C. Rasmusson, D.D. Stuthman and S.E. Nickel. 1995. Alfalfa Establishment with barley and oat companion crops differing in stature. Agronomy Journal 87: 268-272.

Tan, M. and Y. Serin. 1998. Determination of suitable companion crop and its cutting stage for alfalfa. Journal of Ataturk University Faculty of Agriculture 29(2): 219-229.

Tan. M. and Y. Serin. 2004. Is the companion crop harmless to alfalfa establishment in the highlands of East Anatolia? Journal of Agronomy and Crop Science 190(1): 1-5.

Tan, M. and Y. Serin. 2013. Forage Crops. Atatürk University Faculty of Agriculture Pub. 190, Erzurum, 222 p.

Tan, M., H.İ. Erkovan and S. Temel. 2009. The effects of seeding times and rates on forage yield of alfalfa. National VIII. Field Crops Congress, October 22, 2009, Hatay, Turkey.

Uygur, F.N. 1985. Untersuchungen zu Art und Bedeutung der Verunkrautung in der Çukurova unterbesonderer Berücksichtigung von Cynodon dactylon (L.) Pers. Und Sorghum halepense (L.) Pers. PLITS 3 (5), Verlag, Stuttgart.

Yildiz, N. and H. Bircan. 2003. Research Design and Methods. Atatürk University Faculty of Agriculture Pub. 697, Erzurum. 